\title{
Application of Marketing Tools of Experiential Marketing in the Internet Sphere \\ ${ }^{1}$ Julia Kurbatova ${ }^{*},{ }^{2}$ Maria Ryabukha \\ ${ }^{1}$ Ph. D., Assoc. Prof., ${ }^{2}$ Student \\ ${ }^{1,2}$ Department of Management of Foreign Economic Activity and Finance, National Technical University "Kharkiv \\ Polytechnic Institute", Ukraine, Kharkov
}

\begin{abstract}
$\underline{\text { Abstract }=}$
7 he article examines the concept of experiential marketing in the context of production promoting in the Internet sphere. Two groups of motives for user interaction with content in the network are identified active and passive. The ways of satisfying the active motives of users in the development of a multimedia product are substantiated. Proposals by the use of tools for the concept of experiential marketing in the Internet sphere, such as values strengthening, coolhunting, brand development, design, theatricalization, personalization and dialogue have been formed.
\end{abstract}

Keywords-experiential marketing, experiential marketing tools, motives for interaction with content, the Internet sphere, multimedia product, efficiency.

\section{PROBLEM STATEMENT}

In the modern world most enterprises operate in the Internet sphere. The driver of sales via the Internet was the development of Internet technologies, availability of mobile devices. There is a transformation of marketing, in connection with the fact that the target audience spends more time in the interaction with mobile phones, tablet computers and laptops. In such conditions it is necessary to search for new means of production promotion [1]. The task of the company is to connect with potential customers via all modern devices in the real time mode and draw attention to its product. In addition, the relevant problem is finding ways to combine the creative and technical side of communication in the Internet sphere. Marketers should develop digital skills for the effective communication with clients [1]. One of the modern concepts of gaining users' attention is the concept of experiential marketing. Using the tools of experiential marketing, the developer can enhance the interest of the target audience to the product and stimulate the fulfillment of the necessary actions - buying, filling out an application, writing a review, etc.

\section{ANALYSIS OF LATEST PUBLICATIONS}

The concept of experiential marketing was studied by J. Pine, J. Gilmore [2], B. Schmitt, D. Rogers, K. Vroszos [3]. The authors develop the idea of the need to perceive business as a show. The seller is a director, and the buyer is a viewer. Technological aspects of the perception of information in the Internet are covered in the works of B. Doerfield [4]. Modern software developers release products for analytics of user's impressions, by recognizing the mimicry of human face. More and more attention of scientific community is focused on finding ways to retain the attention of potential customers, forming impressions based on the use of technical and content side of multimedia products. The task of keeping attention and creating impressions is complicated by informational noise in the Internet sphere, on the one hand, and high rates of development of information technologies for transferring the content to the user, on the other.

An unresolved problem is the generalization of approaches to the use of experiential marketing tools in the Internet sphere. Experiential marketing is based on the formation of users' emotions during the products promotion. The impressions of the user to the purchase or performance of a target action. Experiential marketing is a creative, intuitive process. Technologies in the Internet sphere used to achieve this goal require skills in programming, design, mathematics, statistics and computer technology.

\section{PURPOSE OF THE ARTICLE}

Development of recommendations on the application of experiential marketing in the Internet sphere. The main tasks of the study are: to justify the expediency of applying the concept of experiential marketing while promoting a product in the Internet sphere; to highlight the motives of users interaction with the content on-line; to form the proposals for the application of impression marketing tools during the development of multimedia products; to substantiate the ways to analyze the effectiveness of the tools used.

\section{MAJOR RESULTS OF THE STUDY}

The concept of experiential marketing is translated from English literally as marketing, based on the experience. The sphere of experiential marketing has a psychological basis. In this context, it is advisable to quote the opinion of $\mathbf{J}$. Coles [5] that the goal of a person's life in gaining experience, the ability to experience and feel. Getting experience 
involves human activity, impressions do not necessarily imply activity - passive contemplation can be enough. As R. Arnheim notes [6], it is a mistake to assume that perception is equivalent to knowledge and understanding. According to R. Arnheim, active consumption is always associated with work and knowledge, passive - with rest and emotions. The work of Sh. Abdulayeva and K. Nikolayev gives an example of passive and active consumption of information. Watching a movie is a passive process, as the viewer consumes the plot developed by the director. Reading scientific literature refers to the active process, because it allows you to formulate new knowledge based on the data you have learned, to involve the processes of synthesis, analysis, generation of new meanings.

In our opinion, the processes of user interaction with content can be divided into active and passive groups depending on the motives [1] (Table 1).

Table I Classification of motives of interaction of users with content in the Internet network

\begin{tabular}{|c|c|c|c|c|c|}
\hline \multirow[t]{2}{*}{ № } & \multirow{2}{*}{$\begin{array}{l}\text { Motives of users in } \\
\text { the Internet sphere }\end{array}$} & \multicolumn{4}{|c|}{ Types of multimedia products } \\
\hline & & $\begin{array}{l}\text { Internet site, } \\
\text { landing page (IP) }\end{array}$ & $\begin{array}{l}\text { Online } \\
\text { store }\end{array}$ & $\begin{array}{l}\text { Pages in social } \\
\text { networks }\end{array}$ & $\begin{array}{l}\text { Mobile } \\
\text { applications }\end{array}$ \\
\hline $\mathbf{1}$ & \multicolumn{5}{|l|}{ Active } \\
\hline 1.1 & socialization & - & - & + & $+/-$ \\
\hline 1.2 & training & $+/-$ & - & - & $+/-$ \\
\hline 1.3 & self-determination & - & + & + & + \\
\hline 1.4 & avoidance of reality & $+/-$ & - & $+/-$ & $+/-$ \\
\hline 2 & \multicolumn{5}{|l|}{ Passive } \\
\hline 2.1 & entertainment & + & - & + & + \\
\hline 2.2 & observation & + & + & + & + \\
\hline 2.3 & aesthetics & $+/-$ & $+/-$ & $+/-$ & - \\
\hline
\end{tabular}

According to many researchers [1,2], the user's active interaction with content generates more vivid impressions, which in turn affects the achievement of target actions, laid down by the developer in a multimedia product (site, mobile application, etc.). In this regard, developers of multimedia products should fully meet the active motives of user interaction. This is possible in two directions: technical and semantic.

\section{A. Technical direction of meeting the active motives of user interaction}

For example, the motive of socialization in social networks can be supported by conducting discussions and interviews on pages of social networks for the exchange of views of the community. For mobile applications - by embedding geolocation functions to find friends; by embedding communication functions with friends within the mobile application. A modern solution in the Internet sphere is augmented reality, the use of this technology, of course, will not leave users indifferent. Particular attention should be paid to the development of interactivity functions for multimedia products to enhance the process of user involvement.

\section{B. Semantic direction of satisfying active motives of user interaction}

For example, the motive for self-determination on the website of an online store can be supported by the function "Leave a review of the product." In the mobile application - the function "Evaluate the mobile application." The motive for avoiding reality in social networks is realized by publishing in groups of such content that is able to mentally transfer the user to the virtual world.

The process of applying the concept of experiential marketing on the one hand involves the analysis of the values and motives of the user as the starting point of product development (the strategy of client following), on the other hand, assumes that a competently developed multimedia product influencing the user's impressions can lead to the achievement of targeted actions, laid down by the developer (the strategy of product following). As O. Chubukova notes, the industry of impressions confirms the thesis that supply causes demand [8]. Impressions are able to sell any goods and services, that is why manufacturers pay much attention to the emotional side of the perception of the goods. In our opinion, it is expedient to analyze both the motives of users, and the strives to create a first-class multimedia product. Let us apply the concept of marketing impressions to the development of a multimedia product. To do this, it is proposed to identify the main tools for marketing impressions and generalize the methods for their application in the process of creating multimedia products (Table 2).

Table III Application of experiential marketing tools in the Internet sphere

\begin{tabular}{|l|l|l|l|l|}
\hline $\begin{array}{l}\text { Instruments of } \\
\text { experiential } \\
\text { marketing }\end{array}$ & Internet site, landing page & Online store & $\begin{array}{l}\text { Pages in social } \\
\text { networks }\end{array}$ & $\begin{array}{l}\text { Mobile } \\
\text { applications }\end{array}$ \\
\cline { 2 - 5 } & $\begin{array}{l}\text { Values } \\
\text { strengthening }\end{array}$ & $\begin{array}{l}\text { storytelling; } \\
\text { customers reviews; } \\
\text { guarantees; }\end{array}$ & $\begin{array}{l}\text { the publication of virus } \\
\text { posts and video; } \\
\text { posts with photos }\end{array}$ & $\begin{array}{l}\text { attractive } \\
\text { description of the } \\
\text { mobile application }\end{array}$ \\
\hline
\end{tabular}




\begin{tabular}{|c|c|c|c|}
\hline & $\begin{array}{l}\text { possibility of return of funds spent; } \\
\text { discounts, promotions, competitions; } \\
\text { illustration of a corporate hero (for example, a } \\
\text { rabbit in a toothpaste advertisement); }\end{array}$ & $\begin{array}{l}\text { "before and after" / "it } \\
\text { was- it became"; } \\
\text { discounts, promotions, } \\
\text { competitions; }\end{array}$ & $\begin{array}{l}\text { in the top-charts } \\
\text { of applications; } \\
\text { spectacular icon; } \\
\text { ease of use; }\end{array}$ \\
\hline \multirow[t]{2}{*}{ Coolhunting } & \multicolumn{2}{|c|}{$\begin{array}{l}\text { analysis of the psychological trends of the target audience and their } \\
\text { actualization in the content; }\end{array}$} & 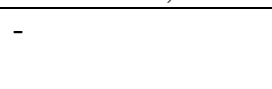 \\
\hline & \multicolumn{3}{|c|}{ analysis of technical novelties and their application in the development of a multimedia product; } \\
\hline \multirow[t]{2}{*}{$\begin{array}{l}\text { Brand } \\
\text { development }\end{array}$} & $\begin{array}{l}\text { work with negative feedback; } \\
\text { reputation in the SERM network; } \\
\text { illustrating certificates, company awards; }\end{array}$ & $\begin{array}{l}\text { publication of posts } \\
\text { within the brand logo; } \\
\text { publication of posts } \\
\text { strengthening the } \\
\text { reputation of the firm }\end{array}$ & $\begin{array}{l}\text { provide the } \\
\text { expected level of } \\
\text { quality of the } \\
\text { mobile application }\end{array}$ \\
\hline & \multicolumn{3}{|c|}{ PR activity to enhance the reputation of the brand on third-party resources (on-line and off-line) } \\
\hline Design & $\begin{array}{l}\text { selection of colors; } \\
\text { analysis of trends in the design of the site; } \\
\text { convenient usability; } \\
\text { adaptability of the website (displaying the } \\
\text { website's interface on different devices); } \\
\text { use of original photos and pictures while } \\
\text { designing the site; } \\
\text { the possibility of increasing the goods, viewing } \\
\text { the texture, etc; 3D tours; A / B design testing }\end{array}$ & $\begin{array}{l}\text { avatar and group } \\
\text { background design; } \\
\text { creation of corporate } \\
\text { headings in a unified } \\
\text { style; } \\
\text { selection of quality } \\
\text { visual content for posts; }\end{array}$ & $\begin{array}{l}\text { search and } \\
\text { implementation of } \\
\text { a unique style of } \\
\text { application } \\
\text { design; }\end{array}$ \\
\hline Theatricalization & $\begin{array}{l}\text { flash animation; flash banners ("roundabout"); } \\
\text { video clips; popup windows; thinking of various } \\
\text { scenarios of user behavior on the site; }\end{array}$ & $\begin{array}{l}\text { posts with videos and } \\
\text { gif-animation; }\end{array}$ & $\begin{array}{l}\text { embodiment of } \\
\text { the scenario in the } \\
\text { process of } \\
\text { interaction with } \\
\text { the application; }\end{array}$ \\
\hline Personalization & $\begin{array}{l}\text { customer development (Custdev); minimal } \\
\text { valuable product (MVP), consumer relationship } \\
\text { management (CRM); }\end{array}$ & $\begin{array}{l}\text { improvement on the } \\
\text { basis of analysis of } \\
\text { publication analytics; }\end{array}$ & $\begin{array}{l}\text { custdev; MVP, } \\
\text { CRM; }\end{array}$ \\
\hline Dialogue & $\begin{array}{l}\text { on-line consultant; Feedback forms; Function } \\
\text { "order call"; }\end{array}$ & $\begin{array}{l}\text { answers to private } \\
\text { messages to the } \\
\text { administrator, feedback } \\
\text { on comments; }\end{array}$ & $\begin{array}{l}\text { Feedback forms; } \\
\text { Function "order } \\
\text { call"; }\end{array}$ \\
\hline
\end{tabular}

Let us consider the tools for marketing impressions, presented in Table 2 more detailed.

\section{A. Strengthening values}

Understanding the motives and values of users is an important information for the developer of a multimedia product. Based on knowledge of the basic values of a potential customer, it is necessary to strengthen the values of the promoted product. The main ways to achieve this goal is storytelling, publication of customer feedback, information on the provision of guarantees and the ability to return the money spent, the provision of discounts, holding shares, etc.

Storytelling is becoming very popular. This tool can be implemented from a technical or a semantic point of view. For example, technically, on a flash banner of an Internet site, a company can post digital stories using a slide show. Each slide of the digital story can be accompanied by sounds in MP3 format. From a semantic point of view, storytelling involves creating stories and legends about the company that causes trust. Stories can highlight the features of the product (uniqueness, environmental friendliness, etc.), company values, personal achievements of the staff, experience of interaction with the brand of the firm's clients, etc. As Pekar V. notes [9], storytelling can lead to a complete rethinking of the product or service, increase customer trust and loyalty. In the opinion of O. Todorova [10] the stories told by the firms are able to "build an emotional connection between the brand and the consumer. After all, they, like brands, rely on values and emotions."

The development of a corporate character can be the element of storytelling. Thus, the company personifies the brand. A corporate hero can be used to form not only a brand of children's themes, but also of an adult. For example, in preparing for the Euro 2012 football championship, the image of a corporate hero was developed.

\section{B. Coolhunting}

The term coolhunting is translated as "hunting for something class, cool." The main object of coolhunting is the search for new currents in the studied medium. In order to search new trends, it is necessary to analyze the interests of the target audience, as well as to study novelties and fashion trends in significant areas of the user, influencing the purchase of the product promoted by the firm. It is important to analyze both technical innovations and psychological trends. An example of technical novelties, for example, is the use of parallax effect when developing a website. This effect allows you to create a multilevel effect and volume on the page while scrolling the page. Let us consider examples of psychological trends in modern society [11]: 
- $\quad$ "live forever" (consumption associated with the idea, "if I do everything correctly - I will live forever);

- $\quad$ "Peter-Pantry" (the elderly have a tendency to consumption of products peculiar to adolescents);

- $\quad$ "exit from the game" (the need for goods that satisfy the desire for a sharp decline in the pace of life);

- "99 lives" (the need for goods satisfying the desire to accelerate the pace of life);

- $\quad$ "hiding in a cocoon" (consumption that does not require personal contacts, associated with the desire to escape life in a narrow environment);

- "You are a family" (single people want to live a full life, buying goods and services that will allow them to do so), etc.

\section{Brand Development}

The brand of the company identifies the manufacturer's products in the total mass. It is known that goodwill (good reputation of the firm) is part of the assets of the enterprise. The development of the company's brand is a means against commoditization. Commoditization is "lowering the value of a brand and moving to competition exclusively in the price plane" [10].

\section{Design}

The design solution in the design of a multimedia product plays one of the main roles in the interaction of the user with the product, forming the first impression and the desire to continue communication with the brand. Design enhances the value of the product being promoted. It is important to keep track of trends in design when developing a multimedia product, and at the same time, to look for your own style of design and corporate identity. To select the best design, use A / V testing as the tool for choosing the best alternative.

\section{E. Theatricalization}

The realization of theatricalization in a multimedia product is a rather difficult task. Theatricalization presupposes the presence of scenario staging and actors (employees of the company, as well as the user involved in the action). For multimedia products, theatricalization is possible on the basis of the use of flash technologies and the embedding of video clips in the content. The basic rules of dramatization [9]: 1) the existence of a script; 2) creating impressions and positive emotions; 3 ) impact on all sensory organs.

\section{F. Personalization}

Personalization is aimed at the desire of the company to fully satisfy the client's desires. The main tools for personalizing a multimedia product are based on creating a primary version of the product and finalizing it based on an analysis of the user's response. Personalization tools include customer development, minimal valuable product, consumer relationship management.

\section{G. Dialogue}

As Pekar V. [9] notes, the dialogue allows to involve the consumer in the process of partnership for creating the best goods, services and impressions. Through the dialogue, the user of the multimedia product becomes a participator in the process of creating the brand. Crowdsourcing projects that involve users in collective creativity are becoming prevalent. An example of a crowdsourcing project is Wikipedia. Marketing impression implies transformation of B2C models - business to business (to business client) in $\mathrm{H} 2 \mathrm{H}$ - human to human (human-to-human).

Any activity should have a result, in this connection it is expedient to track the effectiveness of using marketing tools for impressions. In the modern scientific literature, there are various approaches to measuring the impressions of users. The first approach is technical, it is based on the software's ability to recognize mimicry of the user's face while interacting with content [4]. The program identifies the main emotions of a person: joy, sadness, anger, fear, surprise, contempt and disgust. Programs that can analyze emotions are FaceReader, eMotion Software, GladOrSad, Noldus

Figure 1 shows a screenshot of the Microsoft Project Oxford interface.
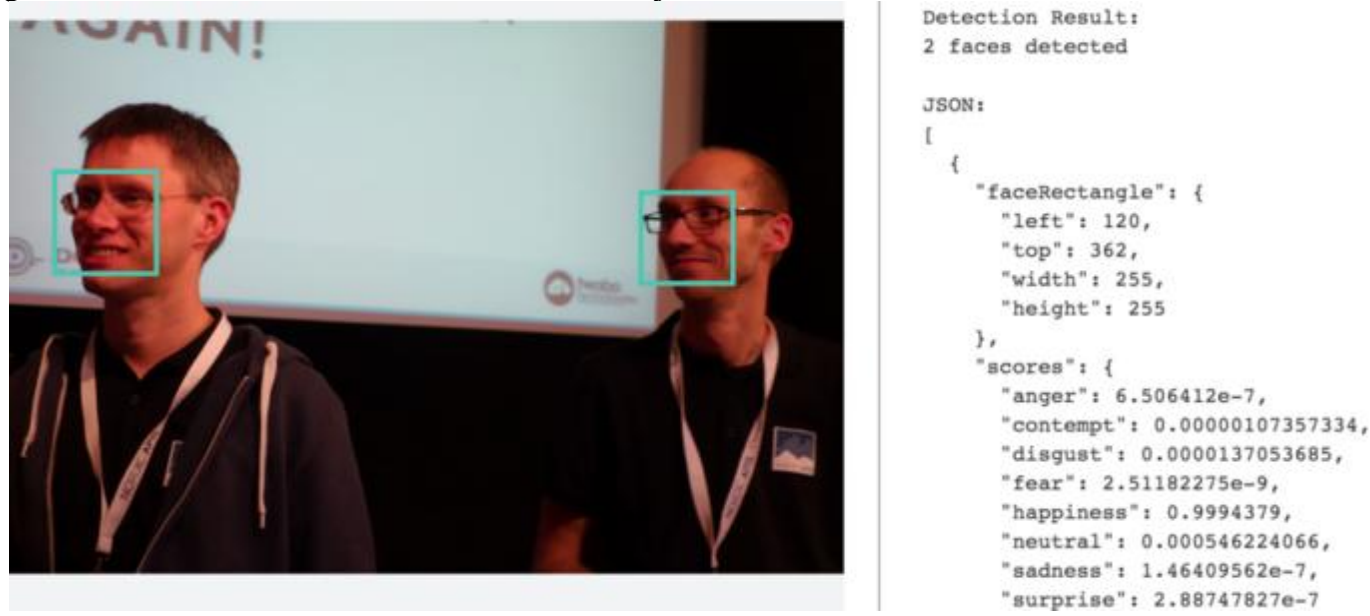

Fig.1 - Microsoft Project Oxford snterface [4] 
Microsoft Project Oxford is an analogue of artificial intelligence. The analysis revealed that the persons of the founders of the project T. Spencer and A. Krohn are 99\% happy and only 0.01831 are sad.

There are programs that can recognize not only static photos, but also the dynamic response of users on-line through a web camera, for example, Sightcorp, Face ++, Imotions, Active Appearance Model methodology and others [4]. The program eMotion Software is known for the fact that its developers have recognized the emotions in the picture "Mona Lisa". The result showed that she was $83 \%$ happy, 9\% showed disgust, $6 \%$ fear and only $2 \%$ Mona Lisa was angry. Unilever has implemented eMotion Software in the ice cream dispenser Unilever Share Happy. If the customers smiled in front of the machine, the ice cream was given for free.

The disadvantages of software for analyzing emotions are:

- the analysis of emotions is possible only for front-line individuals (deviations of 15 degrees are possible, but not more);

- great importance is the lighting (the image of the face in the shadow of the program does not recognize).

Figure 2 shows a screenshot of the Sightcorp interface.

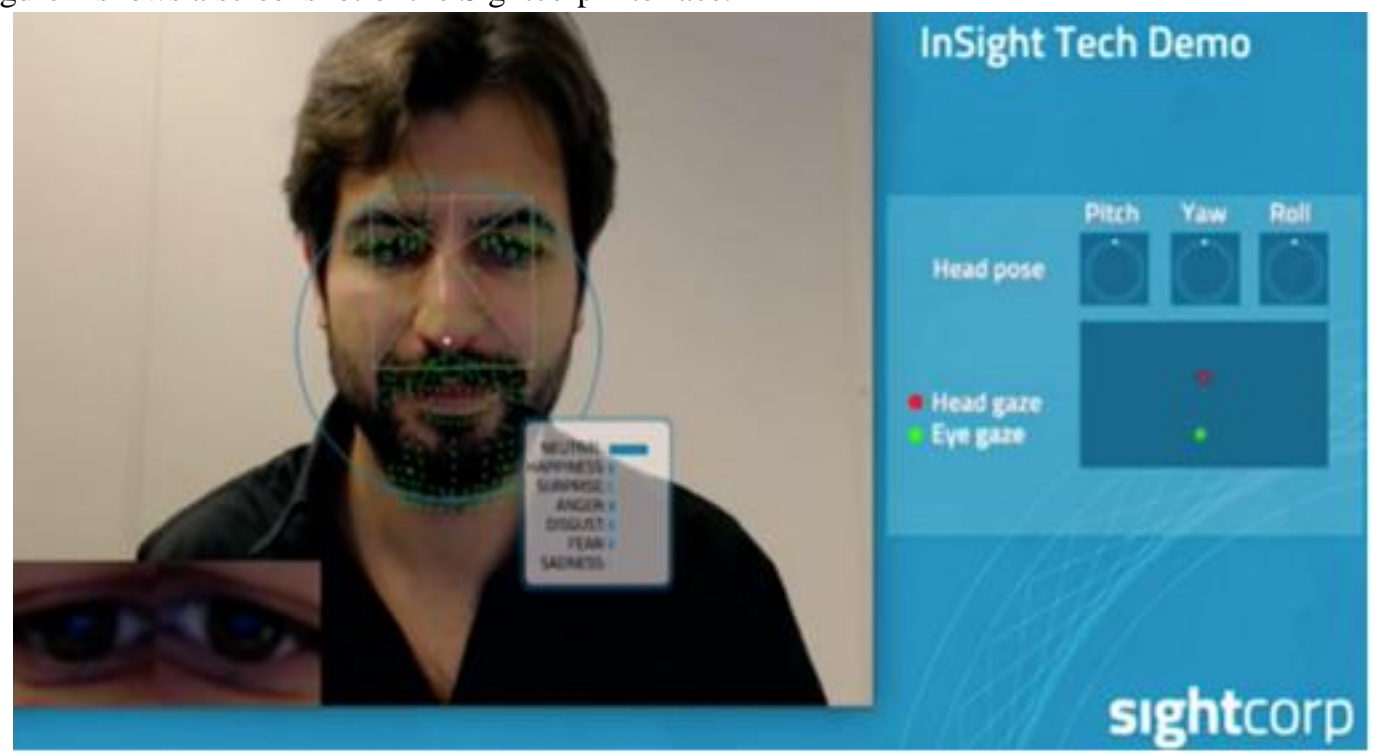

Fig.2 - Sightcorp interface [4]

The technical method can include the metrics of the such programs as: Google Analitics, Yandex. Metrics, etc., allowing to measure the involvement of users, based on data on the time spent on the site, the number of pages viewed.

The second approach is communicative. To find out the impressions of users while interacting with a multimedia product, it is possible on the basis of conduction on-line and off-line surveys of control groups. However, the results of the method do not always give an objective assessment. A more detailed study of ways to analyze user experiences requires further research.

\section{CONCLUSIONS}

The urgency of applying the concept of marketing impressions in the development of multimedia products is substantiated. The motives of users during the interaction with content on the network are generalized, active and passive groups are also highlighted. The need to satisfy the active motives of users is proved, as this will increase the likelihood of achieving the target actions laid down by the developer. Methods for using marketing tools for impressions in the Internet sphere for the development of multimedia products are suggested.

\section{REFERENCES}

[1] A. Jacobson (2014). "How technology is changing marketing", [Online]. Available: https://www.theguardian.com/media-network/media-network-blog/2014/sep/29/technology-changingmarketing-digital-media

[2] B. D. Payn, H. D. Gilmor (2005). "Economy of impressions". SPb.VIlyams, 304 p.

[3] B. Shmitt, D. Rodzhers, K. Vrotsos (2003). "Business in the style of the show. Marketing in the culture of impressions". Fair-Press, 298 p.

[4] B. Doerrfeld (2015). "20 emotion recognition APIs that will leave you impressed, and concerned" [Online]. Available: http://nordicapis.com/20-emotion-recognition-apis-that-will-leave-you-impressed-and-concerned/ J. Claus (2008). "Money is love, or something to believe in". SPb.Ves, 224 p.

[6] R. Arnheim (2012). “Art and visual perception”. SPb. Progress, 392 p.

[7] K. Nikolaev, Sh.Abdullaeva (2016). "Intellectual stroke: how to remain a human being in the world of robots and not lose oneself". Moscow, Mif, 288 p. 
[8] O.Chubukova, A.Yarenko (2016). "The economy of impressions: the prerequisites for the birth, the main ideas, the economic", KNUTD Journal Vol 6, No.105, pp. 92-98.

[9] V. Pekar (2008). "Introduction to the Economy of Impressions" [Online]. Available: http://pekar.in.ua/ExperienceEconomics.

[10] O Todorova (2016). "Storytelling as innovatively PR tools" [Online]. Available: http://www.acmu.com.ua/presscenter/articles/238/

[11] V. Pekar (2013). "Money and Trends" [Online]. Available: http://www.management.com.ua/marketing/mark251.html 